\title{
Adolf Hitler and the psychiatrists: Psychiatric debate on the German Dictator's mental state in The Lancet
}

\section{Robert M Kaplan ${ }^{*}$}

Clinical Associate Professor, Graduate School of Medicine, University of Wollongong, Australia

${ }^{*}$ Corresponding author: Robert M Kaplan, Clinical Associate Professor, Graduate School of Medicine, University of Wollongong, Australia, E-mail: rob@rmkaplan.com.au

Citation: Robert M Kaplan (2017) Adolf Hitler and the psychiatrists: Psychiatric debate on the German

Dictator's mental state in The Lancet. J Forensic Sci Criminol 5(1): 101. doi: 10.15744/2348-9804.5.101

Received Date: September 23, 2016 Accepted Date: February 25, 2017 Published Date: February 27, 2017

\begin{abstract}
Adolf Hitler's sanity was questioned by many, including psychiatrists. Attempts to understand the German dictator's mental state started with his ascension to power in 1933 and continue up to the present, providing a historiography that is far more revealing about changing trends in medicine than it is about his mental state.

This paper looks at the public comments of various psychiatrists on Hitler's mental state, commencing with his rise to power to 1933 and culminating in defeat and death in 1945. The views of the psychiatrists were based on public information, largely derived from the news and often reflected their own professional bias.

The first public comment on Hitler's mental state by a psychiatrist was by Norwegian psychiatrist Johann Scharffenberg in 1933. Carl Jung made several favourable comments about him before 1939.

With the onset of war, the distinguished journal The Lancet ran a review article on Hitler's mental state with a critical editorial alongside attributed to Aubrey Lewis. A series of letters followed offering largely contrary views, including defensive responses from a regular commentator, William Brown.

Two reports in the USA, only to be published after the war, used prevailing psychoanalytic ideas to analyses the mind of the dictator.

The practice of psychohistory, making diagnoses of historical or political figures, is controversial and raises ethical issues. The Lancet assessments of Hitler's mental state were couched in highly technical language which would meant little to the lay public and disagreement among the contributors negated any chance of a uniform view; instead they reflected the divisions in British psychiatry.

For historians the matter was to be approached with the greatest of caution. Leading figures in the field has dismissed psychologizing as useless in the case of Hitler. The only likely benefit of the exercise is historiographic. While the mind of Adolf Hitler remains a continuing source of interest, the opinions expressed tell us more about those who made them than the subject.
\end{abstract}

Keywords: Psychohistory; Historiography; Psychiatry; Psychopaths

\section{Introduction}

From an early stage of his career, Hitler's behavior was so manifestly extreme, despite his seemingly rational political goals, that his sanity was questioned by many, including psychiatrists. Attempts to understand the German Fuhrer's mental state started with his ascension to power in 1933 and continue up to the present, providing a historiography that is far more revealing about changing trends in medicine than it is about his mental state.

This paper looks at the public comments of various psychiatrists on Hitler's mental state, commencing with his rise to power to 1933 and culminating in defeat and death in 1945. The views of the psychiatrists were based on public information, largely derived from the news and often reflected their own professional bias.

For understandable reasons, comment by German psychiatrists on Hitler's mental state once he came into power was muted. A notable exception was Ernst Kretschmer, a distinguished academic, who said "There's something strange about psychopaths. In normal times we write expert evaluations on them; in times of political unrest, they rule us" - and was lucky to get away with his life [1].

The first public comment on Hitler's mental state by a psychiatrist was by Norwegian forensic psychiatrist Johann Scharffenberg who, in a series of 16 articles in the Oslo Arbeiderbladet in 1933, diagnosed Hitler as a destructive paranoid prophet [2]. These views, unsurprisingly, so enraged the German Legation that they delivered several official protests claiming Scharffenberg was offending a foreign head of state. Eventually charged with the archaic offence of lesé majesty, Scharffenberg had no difficulty 
defending himself and the case was thrown out of court [3]. The Nazis however did not forget and, after the occupation of Norway, imprisoned him (but, astonishingly, released him for fear of the public reaction) [4].

The next public comment on Hitler's personality was by the Swiss psychiatrist Carl Jung in 1939 [5]. Jung perceived Hitler through the lens of his belief in the collective unconscious and the role of messianic figures. Claiming to have met both Hitler and Mussolini in Berlin (this must be questioned), Jung found Mussolini an "original man" with warmth and energy, whereas Hitler inspired only fear. He never laughed and appeared as if he was "in a bad humor, sulking." Jung found him sexless and inhuman with the single purpose of establishing the Third Reich to overcome all Hitler's perceived threats and previous insults in Germany's history. To this he was to add that Hitler had no true self, but functioned as a channel for needs of the German people, consistent with his role as a messianic figure.

Jung's attitude towards the Nazis, which included Hitler, was a source of much controversy after the war. Although he claimed to have distanced himself from the Nazis by 1939 and aided Jews to escape persecution, the most damning indictment was his involvement in the General Medical Society for Psychotherapy (Allgemeine Ärztliche Gesellschaft für Psychotherapie) established by Matthias Göring to eradicate the Jewish influence in psychotherapy [6]. Richard Noll has showed the extent of Jung's identification with Nazi ideals until well into the 1930s before trying to extricate himself as the war progressed [7].

With war inevitable, a two-page article by Medicus entitled "A Psychiatrist looks At Hitler" appeared in the New Statesman [8]. Medicus commenced by warning of the risks of making long range 'medico-psychological' estimates of Hitler; any attempts should be strictly impartial and restricted to the known facts. Despite this warning, his findings were largely drawn from the memoir by the unfortunate Hanisch who had known Hitler during his down-and-out days in Vienna and later died during imprisonment by the Gestapo. Hanisch's posthumous memoirs are not regarded as entirely reliable. From this Medicus determined that Hitler had 'frightful unconscious rage' towards his mother which made him unable to love and extremely aggressive. Recent statements showed the precursory signs of possible psychological failure. While he was not yet mentally ill, in the long run 'a purely pathological outcome is not at all excluded.'

William Brown, who was to establish himself as the most prominent British analyst of the Hitler personality, had treated battle stress cases during the First World War. Commencing as a neurologist, he went on to be director of the Institute of Experimental Psychology, psychotherapist to King's College Hospital and director of experimental clinical research at Bethlem Royal Hospital. Heavily influenced by psychoanalytic ideas, Brown aired his views on fascist dictatorships on several occasions, but his first comment on Hitler was on the eve of war in 1939 [9-12]. In The Times Brown wrote that Hitler had "...every symptom of the paranoiac who is suffering from persecutory mania and whose brainstorms and megalomania will increase until his madness is so apparent that he must be isolated. His messianic identification with Frederick the Great and Napoleon made him appear to be an atavistic monster. His paranoid tendency produced collective paranoia. In Freudian terms his latent homosexuality had been repressed, producing instead self-love and love of Germany [13]." While he could stave off insanity, defeats in the field and the necessity for "terrible decisions" could push him into madness or suicide.

Brown was not alone. Time Magazine, a publication with world-wide distribution, claimed that 13 prominent psychiatrists (alas, unnamed) had diagnosed Adolf Hitler as a paranoiac and prophesied the Fuhrer's mental collapse [14].

With the onset of war began the debate in the august pages of The Lancet, the leading British journal of its kind and subscribed to by doctors round the world. For many psychiatrists it was the first venue for publishing their work, as it was for other specialists. The Hitler debate commenced on 6 January 1940 with A Psychiatrist Looks at Hitler by an unnamed author [15]. Biographical information on Hitler was derived from sources such as Konrad Heiden and Neville Chamberlain. The author commenced by distancing himself from the dilettantism of 'pathography', stressing that such assessments should be done with caution on the available evidence; Hitler's strikingly abnormal personality assisted the task. The author did not agree with Dr. Brown or the Time Magazine psychiatrists that Hitler was paranoid. According to the criteria in Kraepelin's textbook, Hitler was a hysterical personality. Typical cases in history were Joan of Arc and Saint Theresa; there were few examples among the political class. For that reason one had to look at figures like Tiberias, Claudius or Caligula to find comparable examples. This was a matter for historians, not psychologists who were, after all, not astrologers but scientists.

The editors allowed the author considerable latitude, if not space for the piece, an indication of the importance they attached to the exercise. At the same time, they qualified it by running alongside a sceptical editorial. The author too was unnamed but it has been widely attributed to Aubrey Lewis; the meticulous style is characteristic of his writing. Lewis immediately dissented from the finding of hysterical personality, as well as hysterical psychopath. While Hitler had been labelled as paranoid, he was not deluded and the term was 'hardly apposite. Instead, the most suitable category was that described by Pritchard as moral insanity, more recently by Henderson as psychopathy. Hitler had elements of hysteria, feelinglessness and fanatical psychopathy. From his wellinformed knowledge of German psychiatry, he cited such eminent sources as Bumke, Lange and Koch, closing with a typical Lewis aphorism. Correct labelling was the beginning, not the end of psychiatric wisdom and regardless whether Hitler was schizoid, fanatical, hysterical or psychopathic, the real problem was not his personality but the disease of which he was a prominent and ugly symptom. 
The disease, it can be assumed, was German nationalism. Lewis was more aware of the malign effects of pre-war Nazism than many would have known. His wife, psychiatrist Hilda Stoessiger, was a Jewish refugee from Germany. In 1937 he refused to visit Germany on his European tour to investigate psychiatric facilities because of Hitler's treatment of the Jews and the euthanasia of psychiatric patients [16].

These two articles set the stage for the debate which followed:

TM Davie, the medical superintendent of the East Riding Mental Hospital in Yorkshire, responded immediately (13 January 1940) to question the diagnosis of hysteria based on Kraepelin. His work was largely superseded by that of Kretschmer; a better example was Jung who understood the collective racial unconsciousness of the German people. Hitler was the focal point of their repressed longings, a saviour and god, symbolic of their repressed longings and ambition. The Germans had a psychosis which was expressed in the psychology of their leader, reiterating comments made in the past by Bishop Butler and Heinrich Heine. Hitler's personality was therefore only the prominent and ugly symptom of the disease from which the nation suffered.

The neurologist Francis Walshe, a leader in his field, would have none of this (27 January 1940), dismissing any psychiatric diagnosis. Hitler was "a nasty piece of work" and throwing different conditions at him did not help. If nothing else, this indicated the gulf between neurology and psychiatry in their ideas of how the mind functioned.

In the same edition, 'Hysterophobe' noted the silence of the German Führer during the war of nerves. If 'Psychiatrist' was right, then he was suffering from hysterical aphonia! (sic) and no one in the Chancellery could do anything (an electric shock or a kick in the pants was recommended) to shock the divinity out of it. Hysterophobe, it seems, could not take the psychiatric diagnosing seriously.

Frederick Dillon, writing from the bastion of Harley Street (3 February 1940), was in agreement with his neurological colleague. Dr. Brown, he stated, could not object to the "apt and entertaining" irreverence of Hysterophobe. Not so long ago he had described Hitler as the greatest German psychotherapist (presumably a reference to Brown's letter to The Times). If so, his treatment consisted of terrorism, deliberate falsification of scientific knowledge and degrading cruelty. On that basis, Dr. Brown's predication of the onset of the Blitzkrieg would be of great assistance to the Emergency Medical Service.

Brown's views on Hitler clearly did not receive universal approval from his colleagues. In his response, published alongside this letter, Brown was driven to state that he had not made a diagnosis, but based his analysis on Mein Kampf, Hitler's broadcast speeches and discussions with several people who knew him. Because of 'irresponsible generalisations' the minimum that could be said must be based on reliable psychological evidence. The hysterical and paranoid tendencies in Hitler's character were useful threads to predict future action; an example of this was the volte face over the German-Soviet pact. Dr Walshe's view notwithstanding, he intended to continue his scientific work whatever lions were in the way or dogs barking at his heels. Just who were the lions and dogs he was referring too was unstated but not difficult to figure out.

GH Crisp (whose status as a psychiatrist is unclear) pointed out that Hitler and Martin Luther had similar mental characteristics. While the latter was intolerant, abusive, prone to outbursts of rage and periods of strange gloom, unlike Hitler, he was convivial, liking both women and wine. While Luther had many faults, notably his obsessive anti-Semitism, Crisp's analogy with Hitler may be unique.

TA Ross (10 February 1940), a contributor to The Lancet on psychiatric topics as far back as 1918, was equally unimpressed and took up Brown's comment on the German-Soviet volte face. Anyone could do this and in Hitler's case being unprincipled was not the same as being paranoid. Dr. Brown should also explain his changed perception of Hitler as therapist of the German nation to a psychiatric patient. Ross ended by sarcastically inquiring whether Hitler had gone off his head after five years as a therapist, or had this merely been an interlude between two psychotic attacks?

CS Rogerson (4 May 1940), at the Cassel Hospital in Penshurst, felt the use of the terms hysterical and paranoid only made it harder to reach the truth about Hitler. Such explanations, for example with Joan of Arc, were too simple and only illustrated the limitations of diagnostic terms.

And on this note, possibly the most impartial of all the comments, ended the Lancet debate on Hitler's mental state.

While this discussion was going on, other psychiatric views on Hitler were aired in North America. In 1942 Canadian psychiatrist WHD Vernon opined that Hitler, whose personality leaned towards the paranoid type, was suffering from hallucinations, hearing voices, paranoia and megalomania, typical of schizophrenia [17]. This was the most extreme diagnosis of Hitler made by any psychiatrist.

In the USA two opinions that were to be publically aired much later were commissioned by the government. In 1943 psychoanalyst Walter Langer was commissioned by the Office of Strategic Services (OSS) to write a review of Hitler (published 30 years later as The Mind of Adolf Hitler) and submitted in late 1943 or early 1944 titled A Psychological Analysis of Adolph Hitler: His Life and Legend [18-20]. Predicting suicide as the "most plausible outcome", Langer declared that Hitler's behaviour was evidence of a weakling masquerading as a bully, and a failure in the role of Fuhrer. He was "probably a neurotic psychopath bordering on schizophrenia." 
Langer's work was described as important "because of its value to the historian; because it was a 'first' for this country's intelligence services; and because of the official recognition of psychoanalysis the assignment implied [21]." The alternate and more realistic view is that the document is only of historical interest due to the unreliability of its descriptions of the evidence and of its interpretations [22]. Much of the review was based on anecdotal information, if not gossip and employing a mode of analysis that would not be used now [23].

The other report is the confidential Analysis of the Personality of Adolph Hitler by psychologist Henry Murray (who also contributed to Langer's report) for the Office of Strategic Services in October 1943 using similar sources as Langer [24]. Murray was unrestrained in his assessment, writing that a thorough study of Hitler's personality was an important contribution to psychiatry and science, in part because he regarded a carefully documented publication of Hitler's behavior as a deterrent to other "would-be Hitlers". Although Hitler's personality fell within the "normal range", he exhibited the classic symptoms of schizophrenia including paranoia and hypersensitivity, panic attacks, irrational jealousy, and delusions of persecution, omnipotence, megalomania and messiahship. Hitler also had experienced hysterical dissociation (as described in the Pasewalk report in Mein Kampf). Hitler's personality type had developing counteractively in response to overcoming early perceived disabilities and weaknesses, to revenge his perceived humiliations, injuries, and insults to his own pride and his imagined pride of Germany.

\section{Discussion}

It is important to understand the methodology and limitations of the process followed in this paper. The intention is to review the public comments of psychiatrists on Hitler's mental state in newspapers, journal articles, magazines and books, the focus being on English-media, notably The Times and The Lancet. No suitable material was found in US journals but the possibility of other material cannot be excluded.

Psychiatrists, like any other group of people, have views on political leadership. However when they make public assessments of such figures it raises a host of ethical issues [25]. The obvious problem is that they have not examined the person on which they are making a diagnosis. Of greater concern is the impact of a psychiatric diagnosis of a public figure. This confirms the opinions of those hostile to the leader, while making his supporters more defensive. The problem of such assessments was raised by David Owen, a neurologist and former foreign minister in his book The Hubris Syndrome: Bush, Blair and the Intoxication of Power [26]. Owen's thesis was that political leaders so affected did not develop a psychiatric disorder, but fell victim to their own hubris with predictable consequences for their leadership.

While it is now considered unacceptable and grounds for potential misconduct, these concerns did not affect psychiatrists in earlier times [27]. Emil Kraepelin, the leading figure in twentieth century psychiatry, had no hesitation in expressing his opinion on those whom he approved (Bismarck and Kaiser Wilhelm) or disapproved (the Weimar leadership) [28]. For good measure, he was prone to pointing out that all Jews and gypsies were thieves and hysterics [29]. His polar opposite Sigmund Freud (although not a psychiatrist, his influence was such that he was regarded by many as that) was equally guilty, writing not just about historical figures (Moses and Leonardo da Vinci) but contemporary politicians such as Woodrow Wilson (but immediately distancing himself from the effort, which was only published long after his death) [30]. Nor were many of his followers, such of Ernest Jones, immune from this tendency.

Hitler was subjected to psychiatric analysis as far back as 1933, coming to a head in the United Kingdom with the articles and letters in The Lancet in 1940. At that stage, The Lancet was the leading outlet for British psychiatrists with the Journal of Mental Science as an alternative. This journal did not publish any articles or letters on the subject of Hitler's mental state, although there were some passing mentions in book reviews [31]. The British Medical Journal, by contrast, did not publish any articles on Hitler. Britain was in a precarious position at the time. The Germans had swept to victory over Poland in 33 days; worse was to follow in Denmark, Norway and then France. British psychiatrists, as much as any other citizens, would be contemplating the country's precarious position and the nature of the man directing the aggression against them.

The question to be asked is whether this was a productive or futile exercise? Hitler's behaviour in the lead up to the war led to widespread public concern (outside Germany) about his mental state. Did it benefit the citizens of Britain, during the worst moments of the war, to have access to the psychiatric opinions?

The answer is no. The Lancet assessments of Hitler's mental state were couched in highly technical language which would have meant little to the lay public. Furthermore, the polar disagreement among the contributors negated any chance of a uniform view; instead they reflected the existing divisions in British psychiatry. Psychoanalytic ideas, while still reluctantly accepted in psychiatric practice, came up against the nosology derived from Kraepelin. Reflecting the widening dichotomy between psychiatry and neurology, Walshe dismissed all speculation, settling instead for the belief that Hitler was "a nasty piece of work". Interestingly for a neurologist, Walshe did not suggest an organic explanation for Hitler's behaviour, something which has received a fillip with recent research that confirmed the presence of Parkinsonism, effects of stimulant medications and raised the possibility of encephalitis lethargica [32]. The difference between the neurological and psychiatric views echoed those at the post-war trial of the Norwegian dictator, Vidkun Quisling. There was an intense dispute over his sanity with the neurologists claiming that he had a brain tumour [33]. 
The only likely benefit of the exercise is historiographic. While Kraepelinian materialist views still prevailed in psychiatry, many saw psychoanalysis as the only system that could explain the variations of human personality. Since then the use of psychoanalysis to examine historical figures (psychohistory) has been subjecting to withering criticism from a number of sources and its use is largely disdained by current historians (although this does not restrain those of Lacanian inclination). It comes as no surprise that Aubrey Lewis, the magisterial influence in British psychiatry at the time, was cynical about the whole exercise.

After the war, the Hitler biographies proliferated, followed by attempts to explain Hitler, mostly on a one-explanation-fits-all basis, including heroic and misguided cases for childhood abuse - quite baseless, Hitler was indulged by his mother and his father, although strict by modern standards, was doing no more than trying to induce some common sense in his dreamy son - and effeminate homosexuality - equally misguided, although Hitler's sexuality remains obscure [34,35]. More substantial analyses, such as by Fritz Redlich, Eberle and Neumann, dismissed such speculation and found that Hitler did not have any psychiatric disorder [36,37].

For historians the matter was problematic and to be approached with the greatest of caution. Alan Bullock, Hugh Trevor-Roper and Ian Kershaw refuted any suggestions that Hitler was seriously mentally disturbed; the latter, for example, dismissed psychologising as useless in the case of Hitler [38]. For a review of the pitfalls, one can read Ron Rosenbaum's attempts to get to the bottom of it all, quoting Alan Bullock's bemusement over the "one-ball” affair (the prolonged public debate over the state of Hitler's genitals) [39].

Scepticism notwithstanding, books and articles on Hitler continue to pour out. One commentator has said that at the present rate only Jesus Christ will have more books published about him. We are left with the view that the mind of Adolf Hitler remains a continuing source of interest but the opinions expressed tell us more about those who made them and when they were expressed than the subject himself.

\section{References}

1. Gestalten GEK (1963) Stuttgart: Thieme Verlag 94.

2. Lavik NJ (1989) A psychiatrist who confronted Nazism. Political Psychology 10: (757-765).

3. Ringdal, Nils Johan (1995) “Scharffenberg, Johan”. In Dahl; Hjeltnes; Nøkleby; Ringdal; Sørensen. Norsk krigsleksikon $1940-45$ (in Norwegian). Oslo: Cappelen. 199-200.

4. Cohen MM, Vidaver-Cohen D (1988) Doctors in wartime: Johan Scharffenberg, prophet in his own country. Pharos Alpha Omega Alpha Honor Med Soc. 51: 28-30.

5. McGuire W, Hull RFC (1977) CG Jung speaking. New Jersey: Princeton University Press.

6. Sorge G (2012) Jung's Presidency of the International General Medical Society of Psychotherapy: New Insights. Jung Journal Culture and Psyche 6: 31-53.

7. Richard Noll, The Jung Cult (Princeton 1994) and The Aryan Christ (New York 1997).

8. Medicus (1939) A Psychiatrist looks At Hitler. The New Statesman 26: 326-7.

9. William Brown (1939) The Times, October 19, p6.

10. William Brown (1935) The Psychology Behind Dictatorship. The Times Sep 6, p6.

11. William Brown (1934) Psychology and War. The Times Dec 21, p8.

12. William Brown (1939) Psychology of War. The Times Feb 09, p10.

13. William Brown (1939) The Make-Up Of Hitler. The Times 19 Oct, p9.

14. Time Magazine(1939) 30 October, p63.

15. The editorial staff of The Lancet were unable to clarify the issue. Personal communication, 2013.

16. Kaplan RM (2015) Psychiatric Tourists in Pre-War Europe: The Visits of Reg Ellery and Aubrey Lewis. International Journal of Humanities Social Sciences and Education. 2: 78-87.

17. Vernon WHD (1942) Hitler, the man - notes for a case history. The Journal of Abnormal and Social Psychology 37: 295-308.

18. Langer, who was not a doctor became the first person admitted to the American Psychiatric Association who lacked a medical degree.

19. Langer Walter C (1972) The Mind of Adolf Hitler: The Secret Wartime Report. New York: Basic Books.

20. Waugh Martin (1974) Review of the Mind of Adolf Hitler. Psychoanalytic Quarterly 43: 124-133.

21. Hans W Gatzke (1973) Hitler and Psychohistory. The American Historical Review 78: 394-401.

22. Hitler as mass killer: A wartime analysis By Benedict Carey (2015). New York Times 1 Apr.

23. Murray HA (1943/2005). Analysis of the personality of Adolf Hitler with predictions of his future behavior and suggestions for dealing with him now and after Germany's surrender. A report prepared for the Office of Strategic Services, October.

24. American Psychiatric Association (1976) The Psychiatrist as Psychohistorian. Task Force Report 11.

25. Owen David (2012)The Hubris Syndrome: Bush, Blair and the Intoxication of Power. Methuen.

26. American Psychiatric Association, ibid.

27. Decker HS (2004) The psychiatric works of Emil Kraepelin: a many-faceted story of modern medicine. Journal of the History of the Neurosciences $13: 248-276$.

28. Shepherd M (1995) Two faces of Emil Kraepelin. Br J Psychiatry 167: 174-83.

29. Solms M (2006) Freud and Bullitt: An Unknown Manuscript. J Am Psychoanal Assoc 54: 1263-1298.

30. SM Coleman (1941) Review of The Human Mind by Murdo Mackenzie, M.D., M.R.C.P. London: J. \& A. Churchill, Ltd. The British Journal of Psychiatry 87: 442 . 
31. SM Coleman (1940) Review of the Neuroses in War Edited by Emanuel Miller. London: MacMillan \& Co., Ltd., 1940. The British Journal of Psychiatry 87: 443-444.

32. Kaplan RM (2015) Was Hitler Ill? A Reply to Eberle and Neumann. German Politics and Society 33: 70-79.

33. Kaplan RM (2012) Norwegian psychiatry and the trial of Vidkun Quisling. Nord J Psychiatry 66: 155-8.

34. Alice Miller (2002) The Ignorance or How we produce the Evil.

35. Lothar Machtan (2001) The Hidden Hitler. Basic Books, New York, USA.

36. Fritz Redlich (1999) Hitler: Diagnosis of a Destructive Prophet, New York.

37. Henrik Eberle, Hans-Joachim Neumann (2012) Was Hitler Ill?: A Final Diagnosis, Cambridge.

38. Trevor-Roper, Hugh: The Last Days of Hitler, Macmillan (1947); Bullock, Alan. Hitler: A Study in Tyranny, London (1952); Taylor, A. J. P. The Origins of the Second World War, Simon \& Schuster (1996).

39. Ron Rosenbaum (1998) Explaining Hitler. The Search for the Origins of His Evil. New York.

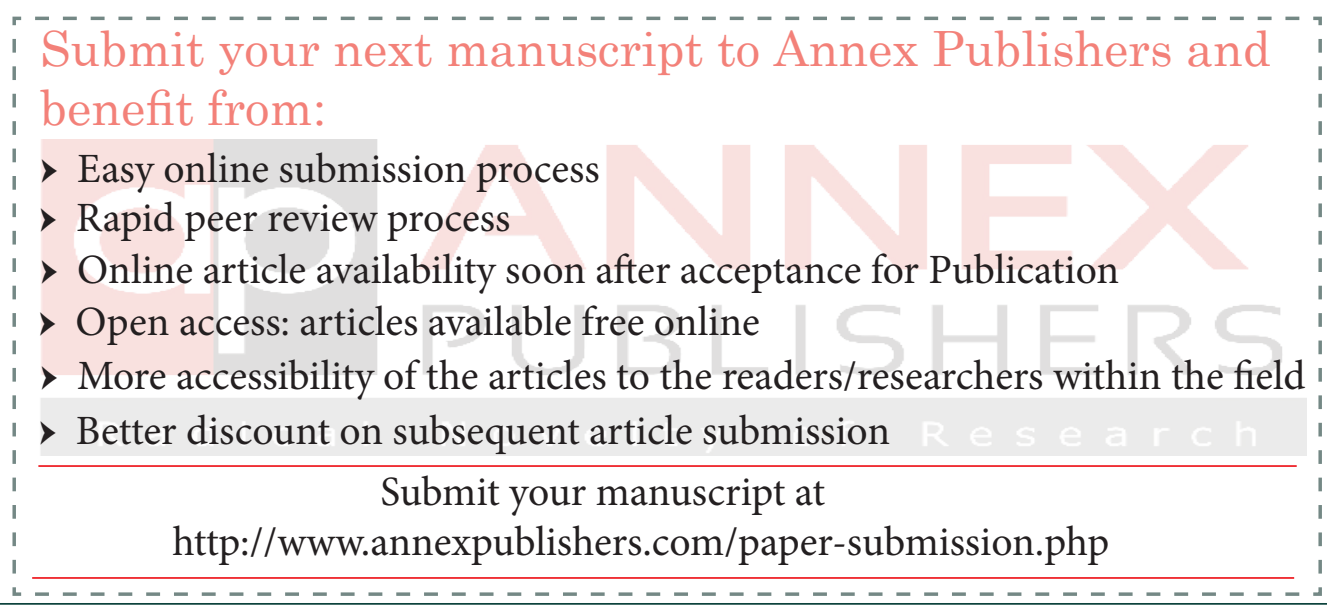

